\title{
Detections of Rainbow Trout Antibodies to Infectious Pancreatic Necrosis Virus and Viral Hemorrhagic Septicemia Virus via a Recombinant Protein-Based Enzyme-Linked Immunosorbent Assay
}

\author{
Cuneyt TAMER ${ }^{1, *}$ (D), Semra GUMUSOVA ${ }^{1}$ id, Harun ALBAYRAK $^{1}$ (D) \\ ${ }^{1}$ Ondokuz Mayis University, Faculty of Veterinary Medicine, Department of Virology, Samsun, Turkey.
}

\begin{abstract}
How to cite
Tamer, C., Gumusova, S., Albayrak, H. (2022). Detections of Rainbow Trout Antibodies to Infectious Pancreatic Necrosis Virus and Viral Hemorrhagic Septicemia Virus via a Recombinant Protein-Based Enzyme-Linked Immunosorbent Assay. Aquaculture Studies, 22(1), AQUAST669.
\end{abstract} http://doi.org/10.4194/AQUAST669

\section{Article History}

Received 12 June 2021

Accepted 02 September 2021

First Online 07 September 2021

\section{Corresponding Author}

Tel.: +903623121919

E-mail: cuneyt.tamer@omu.edu.tr

\section{Keywords}

ELISA

IPNV

Recombinant protein

VHSV

\begin{abstract}
Infectious Pancreatic Necrosis Virus (IPNV) and Viral hemorrhagic septicemia virus (VHSV) cause significant losses in the aquaculture industry. There have been few reports of the use of screening rainbow trout for antibodies against IPNV and VHSV as an epidemiological tool. Several ELISAs using a whole virus or recombinant IPNV and VHSV proteins have been described. In this study, a recombinant protein-based enzyme-linked immunosorbent assay (ELISA) for the detection of IPNV and VHSV antibodies in rainbow trout (Oncorhynchus mykiss) was evaluated. To develop recombinant protein-based enzyme-linked immunosorbent assays, a fragment containing the entire length of the gG gene of VHSV and VP2 of IPNV was amplified by PCR using the viruses' genomic RNA and cloned in pET-28a(+) plasmid. Recombinant structural viral proteins (rVP2 and rgG) were expressed in the Escherichia coli BL21 (DE3). The rgG was extracted and purified. 96-well plates were coated with VP2 and gG separately. For VHSV, Assay could detect until 1/15625 dilution in VHSV positive fish serum. For IPNV, Assays could detect until 1/3125 dilution in IPNV positive fish serum. These results show rgG and rVP2, used in ELISA, are more sensitive than virus neutralization tests.
\end{abstract}

\section{Introduction}

Viral hemorrhagic septicemia (VHS) is a systemic infection of several salmonids, and a growing list of marine and freshwater fish caused by viral Piscine novirhabdovirus belong to Rhabdoviridae. VHSV has now been isolated from some 80 species of fish throughout temperate areas of the Northern Hemisphere (Smail, 1999; OIE, 2021). Rainbow trout (Oncorhynchus mykiss) are among the most affected species for VHSV, with losses also occurring in farmed Japanese flounder (Paralichthys olivaceus) and turbot (Scophthalmus maximus) (Isshik et al., 2001; Nishizawa et al., 2006). The presence of the Virus in Turkey was first reported in 2005 (Nishizawa et al., 2006; Albayrak et al., 2018). IPNV is a member of the Aquabirnavirus belong to Birnaviridae, causes significant losses in salmonid and non-salmonid fish species in the World (Albayrak and Ozan, 2010; Moreno et al., 2014). It is also fairly widespread in Turkey (Albayrak and Ozan, 2010). The IPNV was first detected in Turkey in 2002 and continues to cause significant economic losses, especially in rainbow trout hatcheries in Turkey (Candan, 2002; Isıdan et al., 2019). Although various vaccine studies are carried out in the world, there is no commercial vaccine against VHSV and IPNV yet (Adelmann et al., 2008; Cuesta et al., 2010; Romero et al., 2011; Sommerset et al., 2003; Tamer et al., 2021a; Tamer et al., 2021b). 
There are several techniques based on antibody detection against viral proteins and many protocols based on amplifying viral gene samples by RT-PCR or Lamp for fish infectious agents (Fregeneda-Grandes and Olesen, 2007; Liu et al., 2008; Pekmez et al., 2020; Rodriguez Saint-Jean et al., 2001; Suebsing et al., 2011; Tamer et al., 2019). The seroscreening method used in the majority of reports of VHSV and IPNV was virus neutralization, which is generally more labor-intensive than virus isolation (Fregeneda-Grandes and Olesen, 2007; Olesen et al., 1993; Tamer et al., 2019). It may explain why the routine screening of fish sera for neutralizing antibodies has not been used more extensively (Olesen et al., 1993; Tamer et al.,2019). ELISA has a high level of sensitivity and reproducibility and allows for automation. Besides, ELISA is the method of choice for screening a large number of serum samples in a short while. There are several ELISA trials to detect VHSV antibodies using recombinant or whole virion of VHSV. But there is no correlation between these studies (Encinas et al., 2011; Fregeneda-Grandes and Olesen, 2007; Hansen et al., 2005). Also, several ELISAs using a whole virion of IPNV protein have been described (Dixon and Hill, 1983). But, there are no commercial seroscreening ELISA kits for these agents yet. This study aimed to develop accessible and sustainable ELISA using recombinant surface proteins to detect rainbow trout antibodies against gG of VHSV genotype le and VP2 of IPNV Sp serotype.

\section{Material and Methods}

\section{Cell Culture and Virus}

Epithelium Papillosum Cyprini (EPC) cells, which was supplemented with Leibovitz's L-15 Medium (L-15) (Gibco, Cat No: 11415-049) contains 1\% antibiotic + antimycotic $(10000 \mathrm{IU} / \mathrm{ml}$ penicillin, $10 \mathrm{mg} / \mathrm{ml}$ streptomycin, $0.025 \mathrm{mg} / \mathrm{ml}$ amphotericin B) (Gibco, Cat No: 15140122), 2 mM L-glutamine (Gibco, Cat No:25030081), 1\% non-essential amino acids (Gibco, Cat No: 11140050), $10 \mathrm{mM}$ Na pyruvate (Gibco, Cat No: 11360070), 1\% Hepes buffer (Sigma, Cat No: H0887$100 \mathrm{ML}$ ) and $10 \%$ fetal bovine serum (FBS) (Gibco, Cat No: A31608), was used to produce both IPNV and VHSV. EPC cell was subcultivated and incubated at $25{ }^{\circ} \mathrm{C}$ incubators.

The VHSV Bolu/06 strain (GenBank Accession Number: KM972678.1) and the IPNV Almus (GenBank Accession Number: MH614929.1) were inoculated to the 24 hours old EPC cells in $75 \mathrm{~cm}^{2}$ tissue culture flasks. Both flasks were incubated at $15{ }^{\circ} \mathrm{C}$, and flasks were checked day by day in terms of cytopathic effect (CPE). Approximately three days later, the cytopathic effect was observed in both IPNV and VHSV infected cells.

\section{gG Gene Amplification with RT-PCR}

Genomic RNA of IPNV and VHSV was extracted by using the RNeasy Mini kit (Qiagen, Cat No: 74106) according to the instruction manual. Following the genomic RNA extraction, PCR amplification was performed with Onestep RT-PCR kits (Qiagen, Cat No:210212) according to the manufacturer's instructions. For both viruses, the reaction mixture contains 0,2 mM dNTP, 0,4 $\mu \mathrm{M}$ each primer (Table 1), 10 $\mu \mathrm{l} 5 \times$ Buffer, $25 \mathrm{mM}$ DTT, $2 \mu \mathrm{l}(1 \mathrm{U})$ enzyme mix, $5 \mu \mathrm{l}$ template RNA and the total volume was 50 ul. For VHSV, the RT-PCR profile was as follows: one cycle for 30 minutes at $50^{\circ} \mathrm{C}$; one cycle for 15 minutes at $95^{\circ} \mathrm{C} ; 35$ cycles for 1 minute at $94^{\circ} \mathrm{C}, 1$ minute at $60^{\circ} \mathrm{C}$, and 1 minute at $72^{\circ} \mathrm{C}$ and a final extension for 10 minutes at $72^{\circ} \mathrm{C}$. For IPNV, the RT-PCR profile was as follows: one cycle for 30 minutes at $50^{\circ} \mathrm{C}$; one cycle for 15 minutes at $95^{\circ} \mathrm{C}$; 35 cycles for 30 seconds at $94^{\circ} \mathrm{C}, 30$ seconds at $60^{\circ} \mathrm{C}$, and 70 seconds at $72^{\circ} \mathrm{C}$ and a final extension for 10 minutes at $72^{\circ} \mathrm{C} .10 \mathrm{ul}$ of the PCR products were observed with gel electrophoresis, which contains $1 \%$ agarose and $0,5 \mu \mathrm{g} / \mathrm{ml}$ ethidium bromide gel in $1 \times \mathrm{TAE}$ solutions. PCR product was extracted from the agarose gel by Qiaquick Gel Extraction Kit (Qiagen, Cat no: 28706).

\section{Cloning, Protein Expressions and Purification}

VP2 and gG genes were cloned into the pET28a vector, which has $\mathrm{T} 7$ promotor, and transferred into BL21 DE3 cells (New England BioLabs, Cat No:0621507) for the protein expression. Pellets were denatured with $8 \mathrm{M}$ urea to resolve insoluble proteins, and the purification process was performed by Qiaexpress Type IV kit (Qiagen, Cat No: 34149). Purified proteins were evaluated by using SDS PAGE and Western Blot previously described (Tamer et al., 2021a; Tamer et al., 2021b).

\section{Covering of Proteins into 96-well Plates}

Both purified proteins (VP2 and gG) were diluted with 0,5 M Bicarbonate solution (Sigma, Cat No:C3041-

Table 1. Whole VP2 gene of IPNV and gG of VHSV primers with restriction sides (Tamer et al., 2021a; Tamer et al.,2021b)

\begin{tabular}{lcc}
\hline Primers & Sequences $\left(5^{\prime}->3^{\prime}\right)$ & Restriction enzyme \\
\hline IPNV F & CGGGATCCATGGAATGGAATACTTTTTTCTT & BamHI GGATCC \\
IPNV R & CCCAAGCTTTCAGACCATCTGACTTCTGGAAA & HindIII AAGCTT \\
VHSV F & CGGGATCCATGAACACAAACAAGGCAACCG & BamHI GGATCC \\
VHSV R & CCCAAGCTTATGCCTTTGACGTGGGCAGGTCACT & HindIII AAGCTT \\
\hline
\end{tabular}


50CAP) as $0.5 \mu \mathrm{g} / 100 \mathrm{ul}$. Each well was covered with 100 $\mu \mathrm{l}$ protein solution. Plates were stored at $+4{ }^{\circ} \mathrm{C}$ overnight, and after incubation, plates were washed with phosphate-buffered saline (PBS containing tween20), and each well was blocked with $100 \mu \mathrm{l} 2 \%$ non-fat dry milk solution (Biorad, Cat No: 170-6404) for 2 hours.

\section{ELISA Trials}

For IPNV, the plate was divided into two: gG coated groups (I, II, III) and gG non-coated groups (IV, V, VI). For each group, we selected three serums for the experiment and Each serum dilution was evaluated for a duplicate. Group I and IV: Dilution of VHSV positive fish serum. Group II and V: Dilution of VHSV positive rabbit serum. Group III and VI: Dilution of unknown fish serum. The serums were diluted five-fold into dilutions in PBS. Each serum dilution was put into duplicates in 96 well plates and incubated for 1 hour at room temperature. Each well was washed with $200 \mu \mathrm{l}$ PBS (containing twin20). Seconder antibody (Mouse anti salmon; Antibodies, Cat No:69116) was added into wells group I, III, IV and VI for an hour. The second antibody (Mouse anti-rabbit; Invitrogen, Cat No: 31213) was added into wells group II and V for an hour. Each well was washed with PBS (containing tween20). Conjugate (Goat antiMouse HRP; Antibodies, Cat No: 22877) was put into wells for an hour and was washed as previously described. $100 \mu \mathrm{l}$ TMB substrate solution was performed into wells for 15 minutes and then $50 \mu$ stop solution was put into wells to stop the reaction.

Plate divided in two as described in VHSV ELISA trials. Group I and IV: Dilution of IPNV positive serum. Group II and V: Dilution of unknown bovine serum. Group III and VI: Dilution of IPNV negative fish serum. IPNV positive trout serums were diluted five-fold into dilutions in PBS. Each serum dilution was put into duplicates in 96 well plates and incubated for 1 hour at room temperature. Each well was washed with $200 \mu \mathrm{l}$ PBS (containing twin20). Seconder antibody (Mouse anti salmon; Antibodies, Cat No:69116) was added into wells for an hour. Each well was washed with PBS (containing tween20). Conjugate (Goat anti-Mouse HRP; Antibodies, Cat No: 22877) was put into wells for an hour and wells were washed as described previously. $100 \mu \mathrm{l}$ TMB substrate solution was put into wells for 15 minutes and then $50 \mu \mathrm{l}$ stop solution was put into wells to stop the reaction.

\section{$\mathrm{SN}_{50}$ Assay}

The $\mathrm{SN}_{50}$ test aimed to determine the antibody titer of the fish. VHSV positive serum and IPNV positive serum are tested to determine the antibody titer of VHSV and IPNV, respectively. For this purpose, each sera sample was diluted with L-15 medium in 96-well plates duplicate, starting from a $1 / 1$ dilution rate to a $1 / 78125$ dilution rate with five-fold dilutions. Then, $50 \mu \mathrm{l}$ of the virus suspension, with a $100 \mathrm{DKID} 50 / \mathrm{ml}^{-1}$ value of $10^{-9.5}$, was added and incubated at $16^{\circ} \mathrm{C}$ for 1 hour. Following this, the EPC cell was diluted with L-15 medium to 600000 cells $/ 100 \mu \mathrm{l}$, added to the wells, and incubated at $16^{\circ} \mathrm{C}$. The results were evaluated under a reverse light microscope after four days (Reed \& Muench, 1938).

\section{Results}

\section{Virus Growth Results}

For both viruses, After 3-4 days of cultivating the viruses on EPC cells, CPE was observed under a reverse microscope (Figure 1). The flasks were removed to the freezers at $-80^{\circ} \mathrm{C}$.

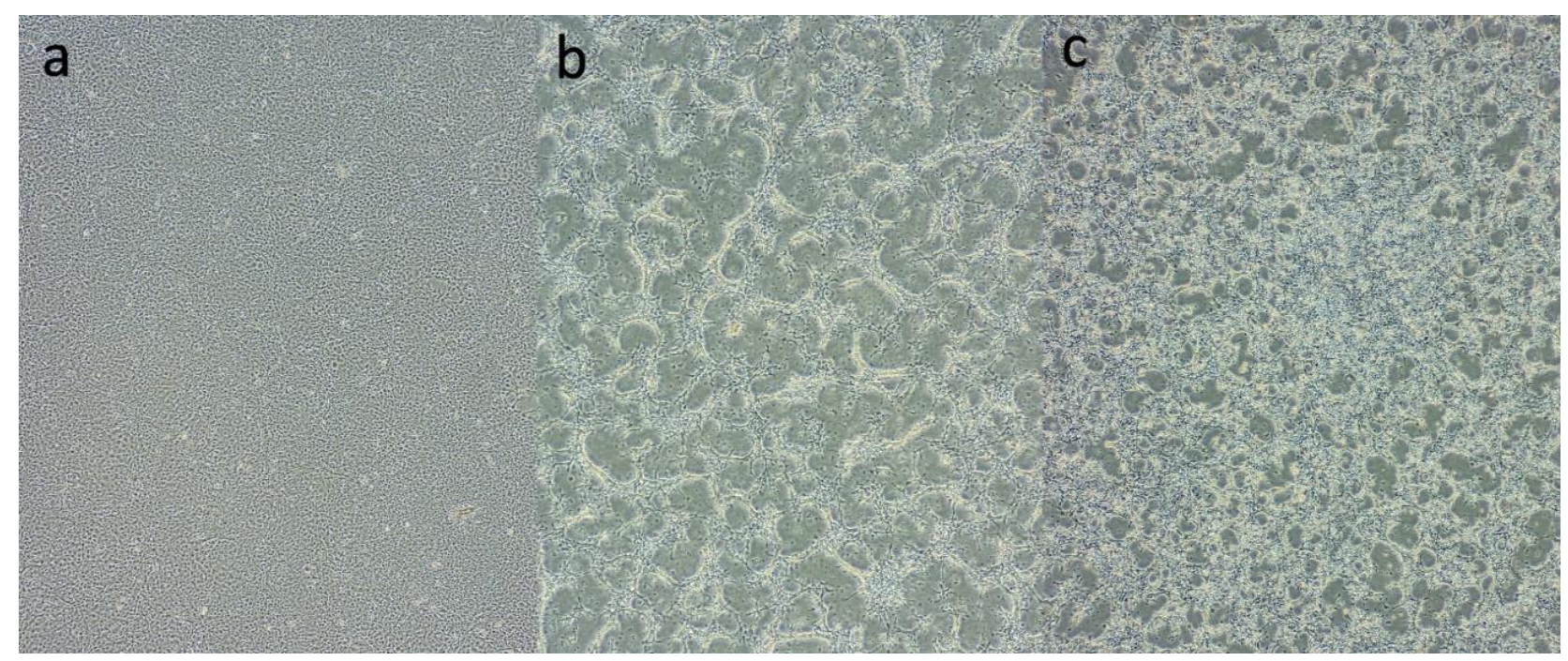

Figure 1. 40x magnification of EPC cells: (a) Cell control at 72 hours post-inoculation; (b) CPE of IPNV at 72 hours post-inoculation; and (c) CPE of VHSV at 72 hours post-inoculation. 


\section{Protein Expression Results}

Ligation and transformation are checked under $1 \%$ agarose gels (Figure 2). Proteins of IPNV and VHSV were evaluated at $50 \mathrm{kDa}$ and $54 \mathrm{kDa}$, respectively (Figure 3).

\section{Elisa Results}

For IPNV, the assay can detect positivities till $1 / 3125$ dilution in IPNV positive fish serum. Besides, no positivity was observed at the non-coated wells (IV, V, $\mathrm{VI}$ ) in IPNV positive antiserums and IPNV negative serum (Figure 4)

For VHSV, the assay can detect positivities until $1 / 15625$ dilution in VHSV positive fish serum. Besides, no positivity was observed at the non-coated wells (IV, $\mathrm{V}, \mathrm{VI}$ ) in VHSV antiserums and VHSV negative serum (Figure 5). These results show rgG can be neutralized to the VHSV positive antiserum only for rainbow trout, but not rabbit positive antiserum.

\section{SN50 Results}

Antibody titer of the IPNV positive fish serum was obtained as $1 / 625$ serum dilution. For VHSV positive fish serum, antibody titer was evaluated as $1 / 625$ serum dilution.

\section{Discussion}

Serologic diagnostic for fish diseases is not common due to the difficulty of taking blood samples from fish. But serologic diagnostic assays are essential for vaccine development studies. Furthermore, both IPNV and VHSV are infections that we know to be persistent (Hershberger et al., 2010; Julin et al., 2015).
For the detection of persistency, in addition to molecular methods, serological diagnostic techniques are also needed. $\mathrm{SN}_{50}$ assay is a reliable but long-lasting test, and it's also a cell-dependent test, so a qualified researcher is required for the $\mathrm{SN}_{50}$ assay. On the other hand, since the amount of serum taken from the fish is low, it is also essential to detect the antibody from smaller amounts of serum. In this study, we developed a rapid, sensitive and cell-independent Enzyme-Linked Immunosorbent Assays against important viral fish pathogens.

The previous studies show that the Plaque neutralization test $\left(\mathrm{PNT}_{50}\right)$ and $\mathrm{SN}_{50}$ test responded better than ELISA, the flow cytometry, indirect immunofluorescence assay, immunoperoxidase assay and immunoblot blot assay for detection of IPNV and VHSV antibodies (Fregeneda-Grandes and Olesen, 2007; Rodriguez Saint-Jean et al., 2001). On the contrary, in our IPNV ELISA trial, there was a close agreement between the ELISA results and a neutralization test for detecting IPNV antibodies when fish sera were tested by both methods. Both tests detected almost the same serum dilution of IPNV positive fish serum. For VHSV, the assay detected $1 / 15625$ dilution of VHSV positive fish serum, whereas the $\mathrm{SN}_{50}$ test detected only $1 / 625$ dilution of VHSV positive fish serum. The results show that the recombinant VP2 protein-based ELISA test is as sensitive as $\mathrm{SN}_{50}$ to detect anti-IPNV rainbow trout antibodies. And recombinant gG protein-based ELISA is more sensitive than $\mathrm{SN}_{50}$ assay to detect anti-VHSV rainbow trout antibodies.

In our ELISA trials, recombinant major capsid proteins (VP2 and gG) of IPNV and VHSV were used for the detection of the viruses. In contrast, whole virion particles were used to neutralize the virus-specific antibodies in SN50 assays. This can be affected the

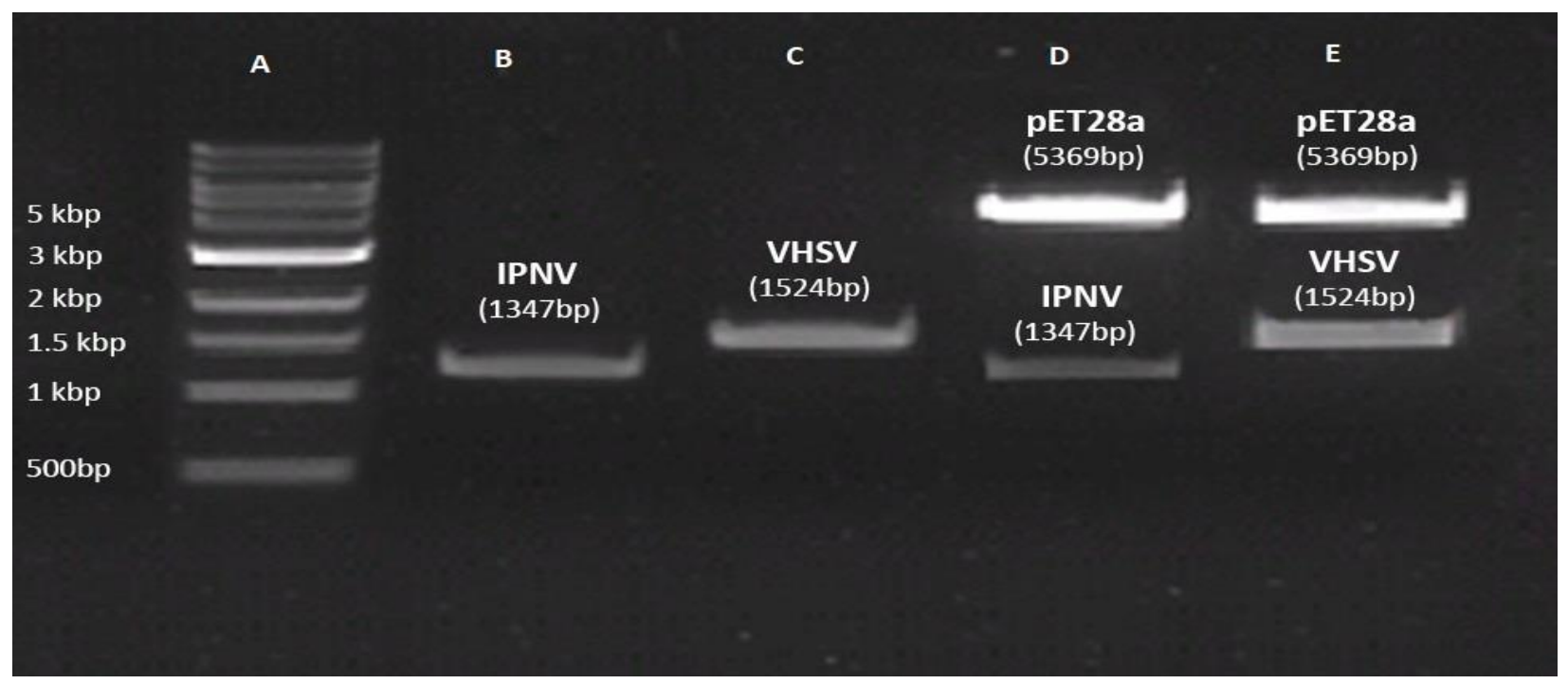

Figure 2. Confirmation of ligation via digestion with restriction enzymes. A: Ladder (New England Biolabs, Cat No: B7025), B: IPNV VP2 gene, C: VHSV gG gene, D: Digested pET28a+IPNV VP2 gene by BamHI HF (New England Biolabs, Cat No: R0136T) and HintIII HF (New England Biolabs, Cat No: R3104T) restriction enzymes, E: Digested pET28a+IPNV VP2 gene by BamHI and HintIII restriction enzymes. 


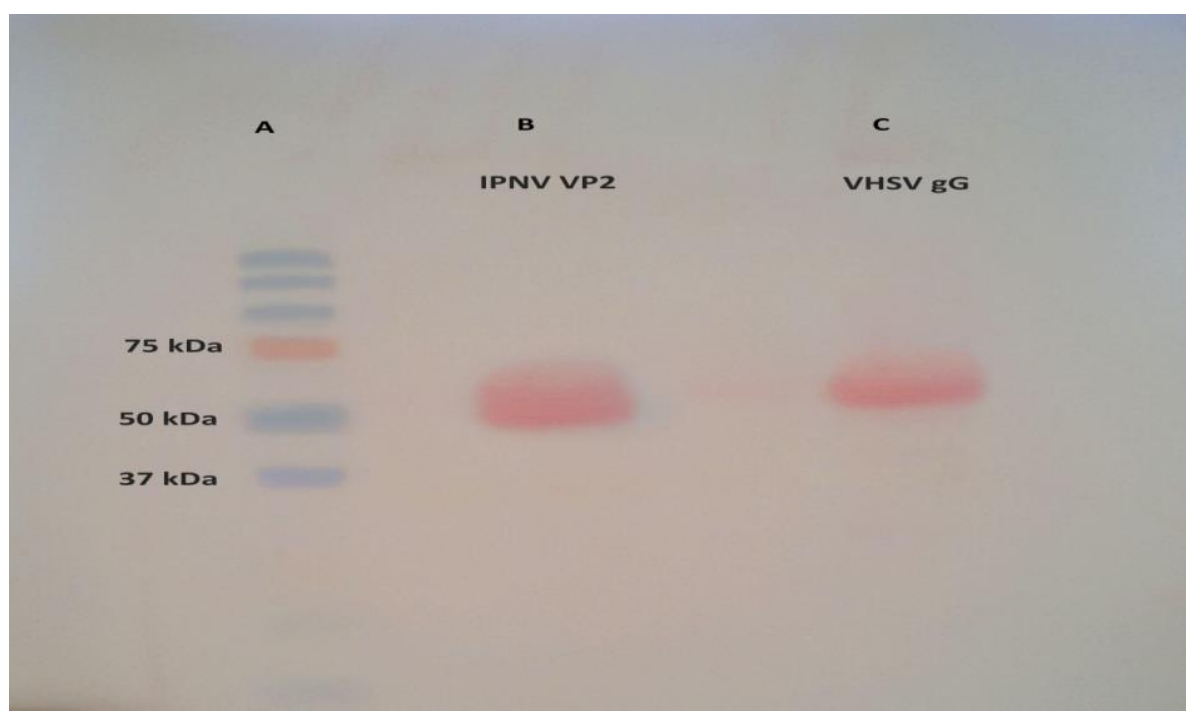

Figure 3. Western blot analyses results. A: ladder (Biorad, Cat No: 1610394), B: IPNV VP2 50 kDa, B: VHSV gG $\sim 54$ kDa

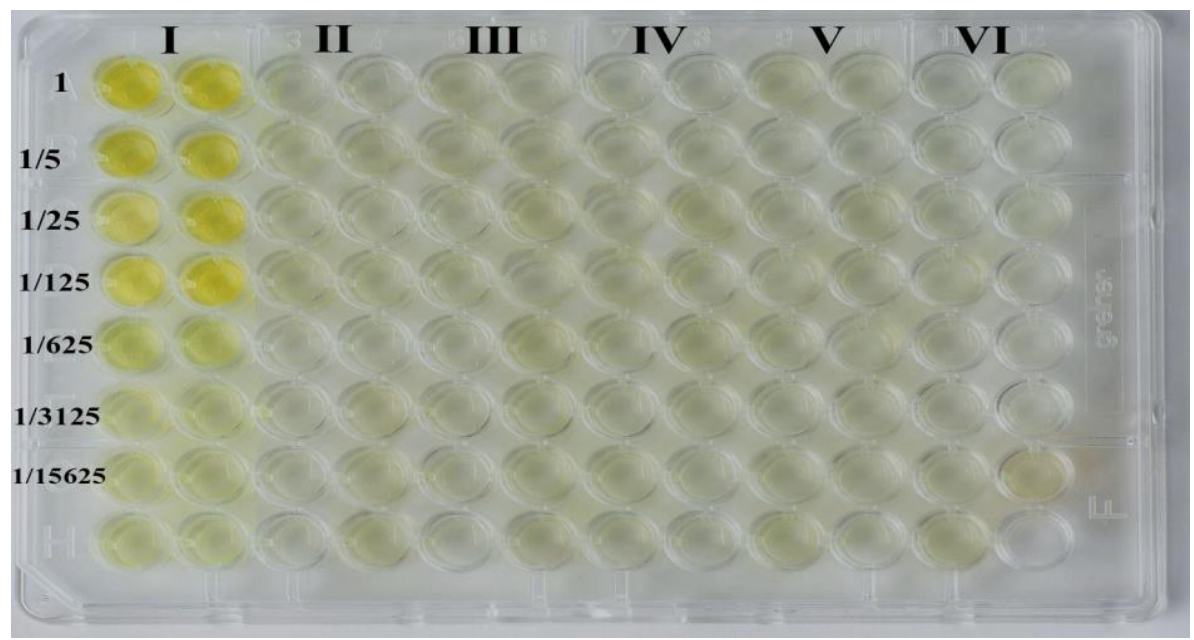

Figure 4. IPNV ELISA assays; I, II, III: were laid with VP2 recombinant protein of IPNV. IV, V, VI: were not laid VP2 recombinant protein of IPNV. I, IV: Dilution of IPNV positive fish serum. II, V: Dilution of bovine serum. III, VI: Dilution of IPNV negative fish serum.

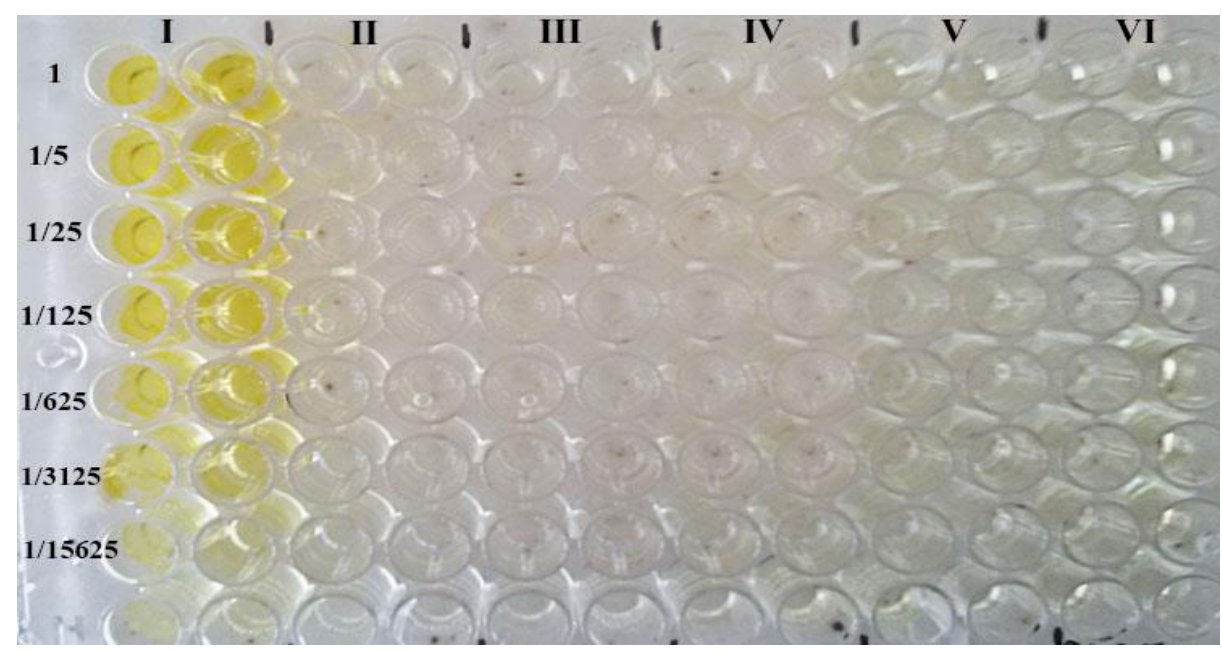

Figure 5. VHSV ELISA assay; I, II, III: were laid with gG recombinant protein of VHSV. IV, V, VI: were not laid gG recombinant protein of VHSV. I, IV: Dilution of VHSV positive fish serum. II, V: Dilution of VHSV positive rabbit serum. III, VI: Dilution of unknown fish serum. 
sensitivity of the assays. The reason of the differences between the ELISA and $\mathrm{SN}_{50}$ assays can be antibodies against different virus epitopes reacted in the two methods. Because the ELISAs, described studies previously and less sensitive than $\mathrm{SN}_{50}$, were designed using whole particle virions (Fregeneda-Grandes and Olesen, 2007; Rodriguez Saint-Jean et al., 2001). Also, in other ELISA studies with recombinant proteins for VHSV, positivity was found up to the same serum dilutions with our study (Encinas et al., 2011).

It is a fact that more sensitive and faster tests are needed than serum neutralization in vaccination studies. These results show us that we can use the recombinant capsid proteins to detect VHSV and IPNV antibodies by ELISA for rainbow trouts.

\section{Ethical Statement}

This article does not contain any studies involving animals performed by any of the authors.

\section{Funding Information}

Funding for this research was provided by the TUBITAK 2214A International Research Fellowship Programme (Grant No: 1059B14800153) and TUBITAK 1001 - The Scientific and Technological Research Projects Funding Program (Project No: 2130156)

\section{Author Contribution}

Design of the study: CT, SG, HA, Laboratory studies: $\mathrm{CT}, \mathrm{HA}$, Writing -review and editing of manuscript: $\mathrm{CT}$, SG, HA.

\section{Conflict of Interest}

The authors declare that they have no known competing financial or non-financial, professional, or personal conflicts that could have appeared to influence the work reported in this paper.

\section{References}

Adelmann, M., Köllner, B., Bergmann, S. M., Fischer, U., Lange, B., Weitschies, W., Enzmann, P. J., \& Fichtner, D. (2008). Development of an oral vaccine for immunisation of rainbow trout (Oncorhynchus mykiss) against viral haemorrhagic septicaemia. Vaccine, 26(6), 837-844. https://doi.org/10.1016/j.vaccine.2007.11.065

Albayrak, H., \& Ozan, E. (2010). Investigating the presence of infectious hematopoietic necrosis and infectious pancreatic necrosis virus infections in rainbow trout (Oncorhynchus mykiss Walbaum, 1792). Veterinary Journal of Ankara University. 52(2), 125-129.

Albayrak, H., Isidan, H., Kalayci, G., Ozan, E., \& Vakharia, V.N. (2018). Genetic analysis of the complete $G$ gene of viral hemorrhagic septicemia virus (VHSV) genotype le isolates from Turkey. Iranian Journal of Fisheries Sciences, 17(1), 67-73.
https://doi.org/10.22092/IJFS.2018.115585

Candan, A. (2002). First report on the diagnosis of infectious pancreatic necrosis (IPN) based on reverse transcription polymerase chain reaction (RT-PCR) in Turkey. Bulletin of the European Association of Fish Pathologists, 22, 45-48.

Cuesta, A., Chaves-Pozo, E., de Las Heras, A. I., Saint-Jean, S. R., Pérez-Prieto, S., \& Tafalla, C. (2010). An active DNA vaccine against infectious pancreatic necrosis virus (IPNV) with a different mode of action than fish rhabdovirus DNA vaccines. Vaccine, 28(19), 3291-3300. https://doi.org/10.1016/j.vaccine.2010.02.106

Dixon, P.F., \& Hill, B.J. (1983). Rapid detection of infectious pancreatic necrosis virus (IPNV) by the enzyme-linked immunosorbent assay (ELISA). The Journal of general virology, 64 (Pt 2), 321-330. https://doi.org/10.1099/0022-1317-64-2-321

Encinas, P., Gomez-Casado, E., Estepa, A., \& Coll, J.M. (2011). An ELISA for detection of trout antibodies to viral haemorrhagic septicemia virus using recombinant fragments of their viral $G$ protein. Journal of Virological Methods, 176(1-2), 14-23. https://doi.org/10.1016/j.jviromet.2011.05.018

Fregeneda-Grandes, J.M., \& Olesen, N.J. (2007). Detection of rainbow trout antibodies against viral haemorrhagic septicaemia virus (VHSV) by neutralisation test is highly dependent on the Virus isolate used. Diseases of Aquatic Organisms, 74(2), 151-158. https://doi.org/10.3354/dao074151

Hansen, J.D., Landis, E.D., \& Phillips, R.B. (2005). Discovery of a unique Ig heavy-chain isotype $(\operatorname{IgT})$ in rainbow trout: Implications for a distinctive B cell developmental pathway in teleost fish. Proceedings of the National Academy of Sciences of the United States of America, 102(19), 6919-6924.

https://doi.org/10.1073/pnas.0500027102

Hershberger, P.K., Gregg, J.L., Grady, C.A., Taylor, L., \& Winton, J.R. (2010). Chronic and persistent viral hemorrhagic septicemia virus infections in Pacific herring. Diseases of Aquatic Organisms, 93(1), 43-49. https://doi.org/10.3354/dao02283

Isıdan, H, Turan, T, Atasoy, M. (2019). Molecular Characterization and Whole Genome Analysis of Infectious Pancreatic Necrosis Virus (IPNV) Isolates Obtained From Turkey. Turkish Veterinary Journal, 1 (1), 1-9.

Isshik, T., Nishizawa, T., Kobayashi, T., Nagano, T., \& Miyazaki, T. (2001). An outbreak of VHSV (viral hemorrhagic septicemia virus) infection in farmed Japanese flounder Paralichthys olivaceus in Japan. Diseases of aquatic organisms, 47(2), 87-99.

https://doi.org/10.3354/dao047087

Julin, K., Johansen, L. H., Sommer, A. I., \& Jørgensen, J. B. (2015). Persistent infections with infectious pancreatic necrosis virus (IPNV) of different virulence in Atlantic salmon, Salmo salar L. Journal of fish diseases, 38(11), 1005-1019. https://doi.org/10.1111/jfd.12317

Liu, Z., Teng, Y., Liu, H., Jiang, Y., Xie, X., Li, H., Lv, J., Gao, L., He, J., Shi, X., Tian, F., Yang, J., \& Xie, C. (2008). Simultaneous detection of three fish rhabdoviruses using multiplex real-time quantitative RT-PCR assay. Journal of Virological Methods, 149(1), 103-109. https://doi. org/10.1016/j.jviromet.2007.12.017

Moreno, P., Olveira, J. G., Labella, A., Cutrín, J. M., Baro, J. C., Borrego, J. J., \& Dopazo, C. P. (2014). Surveillance of viruses in wild fish populations in areas around the Gulf 
of Cadiz (South Atlantic Iberian Peninsula). Applied and environmental microbiology, 80(20), 6560-6571. https://doi.org/10.1128/AEM.02090-14

Nishizawa, T., Savas, H., Isidan, H., Ustündağ, C., Iwamoto, H., \& Yoshimizu, M. (2006). Genotyping and pathogenicity of viral hemorrhagic septicemia virus from free-living turbot (Psetta maxima) in a Turkish coastal area of the Black Sea. Applied and Environmental Microbiology, 72(4), 2373-2378.

https://doi.org/10.1128/AEM.72.4.2373-2378.2006

Olesen, N. J., Lorenzen, N., Jørgensen, P. E. V. (1993). Serological differences among isolates of viral haemorrhagic septicaemia virus detected by neutralizing monoclonal and polyclonal antibodies. Diseases of Aquatic Organisms, 16, 163-170. https://doi.org/10.3354/dao016163

OIE (Office International des Epizooties). (2021) Manual of Diagnostic Tests for Aquatic Animals. https://www.oie.int/doc/ged/D6505.PDF (Accessed at 09.03.2021)

Pekmez, K., Kalaycı, G., Gurhan, S.i.., \& Tuna, E. E. (2020). Preparation and optimization of rapid and sensitive coagglutination test for detection of infectious pancreatic necrosis virus (IPNV). Turkish Journal of Veterinary and Animal Sciences, 44(5), 1003-1009. https://www.oie.int/10.3906/vet-2002-61

Rodriguez Saint-Jean, S., Borrego, J.J., \& Perez-Prieto, S.I. (2001). Comparative evaluation of five serological methods and RT-PCR assay for the detection of IPNV in fish. Journal of Virological Methods, 97(1-2), 23-31. https://doi.org/10.1016/s0166-0934(01)00329-9

Romero, A., Dios, S., Bremont, M., Figueras, A., \& Novoa, B. (2011). Interaction of the attenuated recombinant rIHNV-Gvhsv GFP virus with macrophages from rainbow trout (Oncorhynchus mykiss). Veterinary immunology and immunopathology, 140(1-2), 119-129. https://doi.org/10.1016/j.vetimm.2010.12.001
Sanz, F. A., \& Coll, J. M. (1992). Detection of hemorrhagic septicemia virus of salmonid fishes by use of an enzymelinked immunosorbent assay containing high sodium chloride concentration and two noncompetitive monoclonal antibodies against early viral nucleoproteins. American Journal of Veterinary Research, 53(6), 897-903.

Smail, D. A. (1999). Viral haemorrhagic septicaemia. In P.T.K. Woo and D.W. Bruno (Eds.), Fish Diseases and Disorders: Viral, Bacterial and Fungal Infections. (pp123-148), CABI Publishing, Oxon.

Sommerset, I., Lorenzen, E., Lorenzen, N., Bleie, H., \& Nerland, A. H. (2003). A DNA vaccine directed against a rainbow trout rhabdovirus induces early protection against a nodavirus challenge in turbot. Vaccine, 21(32), 46614667. https://doi.org/10.1016/s0264-410x(03)00526-7

Tamer, C., Durmaz, Y., Palancı, H.S., Özan, E., Kadı, H., Yazıcı, Z., \& Albayrak, H. (2019). A serological survey on Infectious pancreatic necrosis virus (IPNV), viral hemorrhagic septicemia virus (VHSV) and Infectious hematopoietic necrosis virus (IHVN) from rainbow trout in Turkey. The Journal of Etlik Veterinary Microbiology, 30(2), 115-119. https://doi.org/10.35864/evmd.609700

Tamer, C., Albayrak, H., \& Gumusova, S. (2021a). Comparison of immune response between Escherichia coli-derived recombinant subunit vaccine and formol-inactivated whole particle vaccine against viral haemorrhagic septicaemia virus (VHSV) in rainbow trout. Aquaculture Research, 52(6), 2706-2714. https://doi.org/10.1111/are.15121

Tamer, C., Cavunt, A., Durmaz, Y., Ozan, E., Kadi, H., Kalayci, G., Ozkan, B., Isidan, H., \& Albayrak, H. (2021b). Inactivated infectious pancreatic necrosis virus (IPNV) vaccine and E.coli-expressed recombinant IPNV-VP2 subunit vaccine afford protection against IPNV challenge in rainbow trout. Fish \& shellfish immunology, 115, 205-211. https://doi.org/10.1016/j.fsi.2021.06.002 